\title{
Prilog tumačenju pojma krajolika kao kulturne kategorije
}

\author{
Biserka Dumbović Bilušić \\ Ministarstvo kulture, Uprava za zaštitu kulturne baštine, Konzervatorski \\ odjel u Zagrebu, Hrvatska \\ e-mail:bbilusic@gmail.com
}

\begin{abstract}
SAŽETAK U radu se analizira sadržajno određenje pojma krajolik, koji je zbog višestrukog značenja često interpretiran na različite načine, što je u hrvatskom jeziku dodatno naglašeno korištenjem i druge riječi za isti pojam - krajobraz. Induktivno deduktivnom metodom analiziran je nastanak i značenje pojma krajolik koji se odnosi na fizički prostor i na njegovu predodžbu. Krajolik kao egzistencijalni prostor predstavlja složeni sustav strukturiran od fizičkih sastavnica, obilježja i procesa te je važan u stvaranju identiteta mjesta. Koncepti "krajobraz" i "krajolik" mogu se pojmovno razdvojiti. Za razliku od krajobraza, koji se odnosi uglavnom na područja u kojima pretežu prirodne sastavnice, pojam krajolik se kao širi pojam odnosi na cjeloviti karakter određenog predjela i pri tome uključuje i ravnopravno povezuje obje grupe sastavnica: prirodne i kulturne, zajedno s pripadajućim nematerijalnim obilježjima. Stoga istraživanje i bavljenje pitanjima prepoznavanja i zaštite krajolika ne može biti predmetom samo jednog znanstvenog područja, već im treba pristupiti kao interdisciplinarnome području.
\end{abstract}

Ključne riječi: krajolik, krajobraz, kulturni krajolik, identitet mjesta, interdisciplinarno područje.

\section{Uvod}

Krajolici su u suvremenom svijetu prepoznati kao jedan od važnih čimbenika prostornog identiteta zemlje, bilo da se radi o krajolicima visokog stupnja prirodnosti ili oblikovanima čovjekovim djelovanjem tijekom vremena. Osim identitetskog, često imaju veliko društveno i gospodarsko značenje. Značajke i vrijednosti krajolika na koje je utjecao čovjek svojom organizacijom, korištenjem ili naseljavanjem u Hrvatskoj su još nedovoljno prepoznate, vrednovane, zaštićene i korištene. Jedan od razloga leži i u različitom tumačenju značenja pojma krajolika. Različita tumačenja u hrvatskim okvirima dovode do nerazumijevanja i prijepora, što se posljedično odražava na pitanjima zaštite i skrbi o krajolicima. Osim što su uz pojam krajolika vezane brojne nejasnoće, neusklađenosti i nesuglasja u sadržajnom pogledu, dodatan problem izaziva i specifičnost hrvatskog jezika koji, prema lingvističkom tumačenju, za isti pojam koristi više riječi: krajolik, krajobraz i pejsaž. Danas se u Hrvatskoj 
pod pojmom „krajolik“/„krajobraz“ u širim, pa i pojedinim stručnim krugovima u pravilu razumijevaju područja prirodnosti, odnosno neizgrađeni, otvoreni prostori i elementi prirode u urbanom okruženju. Javljaju se i prijepori pojedinih znanstvenih područja i institucija koje se smatraju primarnima i nadležnima za bavljenje pitanjima krajolika/krajobraza. Kroz analizu nastajanja te određenje pojmova „krajolik“ i „kulturni krajolik“ utvrdit će se da je krajolik antropogena, kulturna kategorija oblikovana međudjelovanjem čovjeka i njegova prirodnog okoliša (Gosden i Head, 1994.:14). Takav zemljopisno određeni teritorij ilustrira razvoj i dosege društvene zajednice koja ga je organizirala, oblikovala i uredila svojim načinom korištenja. Krajolik koji je očuvao vrijednosti svjedočanstva zajednice i ljudi koji su ga tijekom vremena oblikovali smatra se kulturnim krajolikom te se u Hrvatskoj prepoznaje i štiti temeljem Zakona o zaštiti i očuvanju kulturnih dobara. Značajni i kultivirani krajobrazi, koji se uglavnom odnose na krajolike visokog stupnja prirodnosti ili na agrarne krajolike, štite se temeljem Zakona o zaštiti prirode. Korištenje riječi „krajobraz“, koja se smatra istoznačnicom pojma „krajolik“, vezano je uglavnom uz prirodne discipline te područje krajobrazne arhitekture, usmjerene prije svega na organizaciju, oblikovanje i hortikulturno uređenje „otvorenih“ i prostora prirodnosti. Cilj je ovoga rada kroz analizu različitih teorijskih pristupa utvrditi značenje i razlike između pojmova „krajolik“, „kulturni krajolik“ i „krajobraz“ kao doprinos njihovu jednoznačnom razumijevanju i tumačenju u Hrvatskoj.

\section{Određenje pojma "krajolik"}

Široko prihvaćeno određenje pojma izneseno je u Europskoj konvenciji o krajoliku ${ }^{1}$ prema kojemu krajolik znači područje percipirano od ljudi čiji je karakter rezultat djelovanja i medudjelovanja prirodnih i/ili ljudskih čimbenika (COE, ELC, 2000., art. 1). Ova se definicija izravno nadovezuje na Humboldtovu definiciju da je krajolik ukupnost aspekata jedne regije (Humboldt, 2010.:14), kao i na vizualno-perceptivna stajališta prema kojima je krajolik dio površine zemlje koji se može obuhvatiti pogledom. Istraživanjima je utvrđeno da krajolik nije statična slika i estetska podloga, već predstavlja okvir čovjekova života koji istovremeno odražava grupe uvjeta (Relph, 1976.:45). Kao odraz različitih grupa uvjeta i mreže međuodnosa čovjeka i njegova prirodnog okruženja krajolik predstavlja međusklop prirode i kulture, materijalne i nematerijalne baštine, biološke i kulturne raznolikosti (Rössler, 1999.:15). Određujuće obilježje krajoliku, kao složenom prostornom entitetu, daje vremenski tijek - povijesno trajanje; krajolik je mjesto na kojemu su uspostavljene strukture $i$ sustavi čovjekove organizacije prostora tijekom vremena (Jackson, 1986.:156). Materijalnu strukturu i prostornu organizaciju krajolika oblikovale su ideje i stavovi ljudi kao i njihov odnos prema okružujućem okolišu, tzv. mentalni čimbenici (Appleton, 1996.:26; Palang, 2003.:8). Stoga sintagma mentalni krajolik uključuje nematerijalne čimbenike koji utječu na krajolik, bilo kroz djelovanje i postupanje s njime ili kroz percepciju čovjeka (Ermischer, 2004.:171).

1 U Hrvatskoj je European Landscape Convention prevedena kao Konvencija o europskim krajobrazima. Ispravnije bi bilo Europska konvencija o krajoliku. U ovom se tekstu koristi potonji prijevod. 
Važno je naglasiti da se pojam „krajolik“ odnosi na cjelokupni prostor, a ne samo na pojedina mjesta; može biti urbani, ruralni, krajolik mora ili kopna, degradirani kao i dobro očuvani, uobičajeni ili iznimne vrijednosti. U krajoliku se reprezentiraju i ostvaruju veze prošlosti, sadašnjosti i budućnosti, prirodnih mogućnosti i ograničenja, ali i različitih kulturnih utjecaja. U njemu su vidljivi utjecaji ljudskih vjerovanja i aktivnosti na pripadajući prirodni okoliš, stoga je on pokazatelj kulturnih uzoraka, vrijednosti i naslijeđa (Aitchson, 1995.; Fairclough, 1999.). Određujuće svojstvo krajolika jest da sadrži fizičku - strukturalnu i nematerijalnu dimenziju te da za razliku od okoliša ne postoji bez čovjekove percepcije (Lothian, 1999.). U dualnosti sadržanoj u samom pojmu krajolika, njegovom dvostrukom značenju primijenjenom na prostor i na prizor koji on reprezentira, neizostavna je uloga promatrača - krajolik se doživljava u odnosu na onog koji ga promatra (Jones, 2003.:80).

Fizička i estetska svojstva krajolika povezuju se i s drugim važnim obilježjem, a to je uloga krajolika u stvaranju geniusa loci (Norberg-Schulz, 1982.:12) i osjećaja mjesta (Jackson, 1986.:41; Gieryn, 2000.:463). U tom su poimanju, osim fizičkih svojstava i čovjekovog utjecaja u procesu stvaranja i oblikovanja krajolika, uključeni estetski i doživljajni čimbenici te nematerijalni elementi i povezanosti, posebice s povijesti, tradicijom i kulturom (Porteaus, 1996.:27). Različite definicije i tumačenja slažu se da je krajolik, kao prostor čovjekova života, važan nacionalni resurs, zajedničko prirodno i kulturno naslijeđe koje je cijenjeno zbog svoje estetske ljepote i doprinosa identitetu područja i osjećaju mjesta (Morris i Therivel, 1995.:78). Većina je europskih krajolika u većoj mjeri kulturno nego prirodno naslijeđe, a nacionalni, regionalni i lokalni identiteti ovise o vrijednostima i povezanostima krajolika sa stanovnicima i posjetiteljima (Kučan, 1998.). Zbog toga je primjereno krajolik razmatrati kao kulturni entitet (Morris i Therivel, 1995.:79) i humani ekosustav čiji se brojni aspekti i sastavnice mijenjaju pod utjecajem različitih prostornih, gospodarskih, povijesnih i ostalih uvjeta (Antrop, 2000.:30). Krajolik je kao sustav osjetljiv na promjene svojih obilježja u cjelini ili pojedinih sastavnica koje mogu dovesti do narušavanja ili u krajnjem slučaju do gubitka identiteta (Bender, 1993.:10).

\section{Nastanak pojma krajolika}

U istraživanju antropologinje T. Keisteri (Keisteri, 1990.) utvrđeno je da se pojam „krajolik“, kao hebrejske riječi nof i jafe, u pisanim dokumentima prvi put javlja u Knjizi psalama (Keisteri, 1990.:161). Riječi talijanskog jezika paesaggio, španjolskog paisaje i francuskog paysage imaju svoj izvor u latinskoj riječi pag nsis. Riječ paysage povezuje riječi „zemlja“ (pay) i „ljudi“ (paysans), koji rade na njoj stvarajući krajolik. Značenje riječi paysage (15. st.) odnosilo se na slikom prikazani izgled određenog područja. Jednako značenje imaju i talijanska riječ paessagio (16. st.) te španjolska paisaje koje također imaju dvostruko značenje, istodobno označavaju i područje i njegovu sliku (Keisteri, 1990.:168). Riječi landscape u engleskom jeziku i Landschaft u njemačkom upotrijebljene su prvi put krajem 15. stoljeća a odnosile su se na prikaze kopnenih prizora u obliku crteža ili slika (Dower, 1993.:18.) Riječ njemačkog jezika Landschaft dvočlana je složenica nastala od imenice Land, „zemlja“, i glagola scapjan/schaffen, „stvoriti“, slično kao i engleska riječ landscape, koja se odnosi i 
na područje i na njegovu sliku. Obje riječi jasno označavaju povezanost krajolika s ljudskim djelovanjem, kao označitelja fizičke scene, ali i njezine slikovne pojavnosti.

Koncept percepcije krajolika ima svoje izvore u europskoj tradiciji pejsažnog slikarstva i literarnog izričaja. ${ }^{2}$ Prvi prikazi krajolika vežu se uz pojavu znanja o perspektivi, sredinom 14. stoljeća, i bili su podloga kompoziciji prizora s ljudskim likovima. Na poznatoj Giorgoneovoj slici Oluja (1508.) krajolik prvi put postaje glavnim motivom i središtem kompozicije slike. Polet ove vrste slikarstva javlja se usporedno s razvojem individualizma, sa željom subjekta da se udalji od kolektivnog iskustva i nastojanjem znanosti da prirodni svijet učini područjem vlastita iskustva i prisvajanja. Pojam krajolika, uspostavljen u prijelaznom razdoblju iz srednjeg vijeka u renesansu, usko je povezan s percepcijom i emocijama čovjeka prema prizorima okružujućeg prostora. Razvojem kulture putovanja krajem srednjega vijeka putnici otkrivaju interes za europske planine, a s pojavom renesanse, osim u slikarstvu, i u poeziji se javlja estetski stav prema prizoru - slici krajolika (Delort i Kuster, 2004.:40). Prizore krajolika do vrhunca je dovelo slikarstvo C. Lorraina, N. Poussina, C. Pissarroa, P. Cezannea i ostalih (Pannell, 2006.:62). Priroda i kultura u zapadnoj su civilizaciji često bile postavljene kao potpune suprotnosti; priroda je bila promatrana ne kao pandan, dopunski dio kulture, već kao neprijatelj kojeg treba kontrolirati i vladati njime pomoću tehnologije i ostalih raspoloživih alata. Tehnološki napredak u industrijskim društvima smatran je putom za zaštitu i izolaciju ljudi od prirode, a prirodne su strukture u najvećoj mogućoj mjeri bile podložne iskorištavanju i kontroli. Takav razvoj, neovisan od prirodnih uvjeta, iskorištavanjem prirode doveo je do sukobljenih odnosa prirode i kulture. Razvitak temeljen na identifikaciji s tehnološkim razvojem dosegao je vrhunac u ranim 1970-im godinama, što je dovelo do reakcije i velikog okolišnog pokreta te prve konferencije UN-a o okolišu u Stockholmu (1972.). Nedugo potom UNESCO je ustrojio međunarodnu Konvenciju za zaštitu svjetskog kulturnog i prirodnog naslijecta ${ }^{3}$ (UNESCO, 1972.), da bi dopunom kriterija za uvrštavanje u Popis svjetske baštine 1992. godine bio uveden pojam kulturnog krajolika (UNESCO, 1992., World Heritage Convention).

\section{Razlika između pojmova krajolika i krajobraza}

Prema lingvističkom tumačenju pojam „krajolik“ označava dio zemljine površine koji se pruža pri pogledu na neko područje, odnosno označava njegov izgled (Anić i Goldstein, 2004.:628). Kao istoznačnice riječi „krajolik“ u hrvatskom se jeziku smatraju riječi: predjel, okolina, pejsaž, krajina i krajobraz (Anić i Goldstein, 2004.:628).

\footnotetext{
2 Ikonografskim početkom svjesne percepcije krajolika smatra se datum 26. travnja 1336. godine kada je pjesnik Francesco Petrarca, popevši se na vrh planine Mont Ventoux, bio ushićen viđenim prizorom te u jednom pismu opisuje svoj pohod na planinu.

3 UNESCO, 1972., Convention Concerning the Protection of the World Cultural and Natural Heritage. 1992. godine na sastanku stručnjaka UNESCO-a u Santa Feu dopunjeni su kriteriji za uvrštavanje u Popis svjetske baštine te je uveden pojam kulturnog krajolika i otvoren put za njihove nominacije. Među prvima bili su nominirani asocijativni kulturni krajolici.
} 
Smatra se da bi najprikladnija hrvatska riječ, ekvivalent pojmovima landscape, Landschaft, paysage bila riječ krajina, koja ima dvostruko značenje - označava granično područje prema drugoj državi, a drugo joj se značenje poklapa s riječi „krajolik“ ili „predio“ (Ladan, 2000.:1018). Riječ krajina dvočlana je složenica od riječi kraj, koja je dio strukture riječi „krajolik“ i „krajobraz“. Prva riječ kraj označava dio zemljišta, naselja i sl., odnosno područje Zemlje, jednako kao i riječ land u anglosaksonskim jezičnim skupinama (Anić i Goldstein, 2004.:628). Međutim uobičajeno korištenje riječi krajina vezano je uz geografsko područje i povijesne okolnosti.

Riječ krajobraz nastala je u drugoj polovici 19. stoljeća s dvama temeljnim značenjima: jedno se odnosi na mjestopisni prikaz (zemljokaz, zemljovid), dok drugo označava mjesto, predio, kraj, krajinu, okolinu, isto što i riječ „krajolik“ (Ladan, 2000.:101). Obje su riječi: krajolik i krajobraz dvočlane složenice i to od riječi kraj i lik, odnosno kraj i obraz. Prvi dio složenice - kraj, jasan je i nije sporan, dok drugi obraz, ima više značenja. Riječ „obraz“ ustrojena je od dvaju dijelova: ob i raz (znači „rez“), pa se temeljno značenje riječi odnosi na ono što je obrezano, izrezano, tj. lik, sliku, kip (Ladan, 2000.:1019). Ostala značenja riječi „obraz“ jesu: lik, oblik, obličje. Značenje riječi $l i k$ također je višestruko i znači ukupnost crta lica, pojavu, obličje; a označava i skup moralnih, misaonih i osjećajnih osobina osobe. Slijedom navedenoga, riječ lik označava šira svojstva, skup osobina, što se u riječi „krajolik“ može interpretirati kao ukupnost svojstava i struktura krajolika - za razliku od riječi „krajobraz" koja se odnosi samo na njegov izgled. Iako je po podrijetlu, tvorbi i značenju „krajobraz“ istoznačnica riječi „krajolik“, prednost joj je dana s lingvističke strane s tumačenjem da se iz riječi „krajobraz“ običnije i lakše izvodi pridjev krajobrazan/ni, za razliku od pridjeva krajoličan/ni, koji nije uobičajen u hrvatskom jeziku. (Ladan, 2000.:1019). Međutim analizom riječi „krajolik“ pokazano je da ima samo jedno značenje i nedvosmisleno označava ono što se u engleskom jeziku naziva landscape. U hrvatskom jeziku dugo je bila u uporabi riječ „pejsaž“/,pejzaž“ sa svojim pridjevom „pejsažni“, primjerice: pejsažno slikarstvo, pejsažna lirika... ${ }^{4}$

U Hrvatskoj su u stručnoj i znanstvenoj literaturi i praktičnoj uporabi sva tri termina: krajolik, krajobraz i pejsaž. Prvi stručni dokument u kojemu se u Hrvatskoj integralno obrađuje problematika krajolika pod naslovom Krajolik - sadržajna i metodska podloga Krajobrazne osnove Hrvatske (*** 1999. a) već u samom naslovu sadrži oba pojma. Iako je u naslovu knjige glavna tema istraživanja nazvana riječju „krajolik“, u tekstu pobližeg određenja koristi se riječ „krajobraz“. U skladu sa suvremenim, interdisciplinarnim pristupima istraživanju krajolika unutar knjige u sektorskim pristupima obrade teme pokazalo se da različita stručna područja koriste riječ „krajolik“, odnosno „krajobraz“. Društvena i tehnička područja uglavnom koriste riječi „krajolik“ i „pejsaž", dok područja biotehničkih i prirodnih znanosti koriste riječ „krajobraz“. Važeći Zakon o prostornom uređenju i gradnji koristi riječ „krajobraz“ i opisuje ga kao: određeno područje, opaženo ljudima, čija je osobnost rezultat međusobnog

\footnotetext{
${ }^{4}$ Danas se riječ „pejsaž“ rjeđe koristi u znanstvenim i stručnim radovima, ali je pridjev pejsažni prisutan u nazivima kolegija akademskih ustanova; na Geografskom odsjeku Prirodoslovno-matematičkog fakulteta i na Arhitektonskom fakultetu.
} 
djelovanja prirodnih i/ili ljudskih čimbenika i koje obilježava prevladavajuća prisutnost prirodnih sastojina. U prvom dijelu objašnjenja pojma koristi dio definicije iz Europske konvencije o krajoliku, uključujući percepciju i međudjelovanje prirodnih i ljudskih čimbenika, ali na kraju dodaje podrobniji opis te su u pojmu krajobraza određujuće prirodne sastavnice (Zakon o prostornom uređenju i gradnji, Pojmovnik). Slično je i u Zakonu o zaštiti prirode u kojemu se koristi riječ „krajobraz" s naglaskom na prirodne elemente. Riječ „krajolik“ upotrebljava se u Zakonu o zaštiti i očuvanju kulturnih dobara, gdje je krajolik ili njegov dio određenog područja koje sadrži karakteristične strukture koje svjedoče o njegovom povijesnom razvoju te se smatra vrstom kulturnog dobra. Ovo određenje pojma krajolika upućuje na očuvane vrijednosti topografski određenog prostora koji je oblikovao čovjek tijekom vremena i koji svojim materijalnim i nematerijalnim obilježjima ilustrira razvoj određene društvene zajednice.

\section{Nastanak i razvoj koncepta krajolika kao znanstvene teme u geografiji}

Početkom 19. stoljeća koncept krajolika u geografiju je uveo A. von Humboldt (1769. - 1859.) definicijom u kojoj je vrlo sažeto i jasno odredio krajolik kao potpuni i cjeloviti karakter jednog područja (Humboldt, 2010.:14). Krajolik, opisan kao ukupnost svih aspekata jedne regije opažene od čovjeka, određen je oblicima, obilježjima, estetskim predodžbama, povijesnim događajima i umjetničkim opisima. Navedenom se definicijom krajolik izjednačava s vlastitom slikom, ali se ujedno određuje i kao posebno područje koje se razlikuje od svoje okoline na temelju prirodnih obilježja i sastavnica stvorenih čovjekovim djelovanjem. Velik doprinos razvitku ideje i sagledavanja krajolika kao fizičkog prostora dao je O. Schlüter (1872. - 1959.), koji u oblikovanju krajolika naglašava utjecaje djelovanja čovjeka. On je prepoznao dva oblika: Urlandschaft, prirodni ili krajolik koji je postojao prije unesenih čovjekovih promjena i Kulturlandschaft, kulturni kao krajolik stvoren djelovanjem kulture. Njegov pristup još uvijek ne uključuje nematerijalne oblike krajolika kao što su klima, gospodarstvo, političke sastavnice, a koje u velikoj mjeri utječu na vidljive oblike u krajoliku. Vidal de la Blache (1845. - 1918.) obrazlaže cjelovitost krajolika (paysage) koji je stvoren društvenim razvojem i oblicima prirodnog krajolika. Krajolike sagledava u njihovoj povezanosti s vegetacijskim obilježjima, estetskim i vizualnim utiscima te stalnim promjenama; krajolik se neprestano mijenja, a njegov trenutni oblik prikazuje njegova ranija obilježja. Koncept se krajolika u prvim desetljećima 20. stoljeća još uvijek odnosio na opisivanje seoskih područja u smislu značenja izraza oblikovati zemlju. Svojom vidljivom površinom prezentira ravnotežu odnosa između prirodnih značajki, načina korištenja zemljišta i naseobinskih struktura u procesima razvoja gospodarskih, političkih i društvenih čimbenika (Claval, 2004.). Na taj je način iskazan stav da je krajolik antropogeni, kulturni entitet te da istraživanje krajolika nužno treba biti usmjereno i na njegovu kulturnu dimenziju (Casey, 1998.:41). Prema suvremenom tumačenju krajolik je opisan kao veći ili manji prostor na površini zemlje, koji se zbog izrazitih posebnosti, zasebne fizionomije razlikuje od ostalih krajolika pri čemu se ta posebna obilježja prikazuju kroz površine, klimu, vodnu mrežu, vegetaciju i naseljavanje sa svojim fizičkim i psibičkim posebnostima, kao $i$ oblicima čovjekovog djelovanja na vjerskom, političkom, gospodarskom, prometnom 
i naseobinskom području. (*** Westermann Lexikon der Geographie, 1973.:297). Ovim pojašnjenjem proširuje se značenje krajolika, ne ograničava se samo na prizor, na ono što određena osoba vidi, već na razlikovna obilježja zemljopisno određenog područja i procese djelovanja čovjeka.

\section{Uspostava i određenje pojma kulturnog krajolika}

Doprinos određenju pojma „kulturni krajolik“, Kulturlandschaft, u Njemačkoj je dao geograf F. Ratzel (1895.-1896.), koji ga određuje kao područje promijenjeno čovjekovim djelovanjem, kao suprotnost primarnom, prirodnom krajoliku. (Ratzel, 1901./1902.:21). Uvodeći pojam u englesko govorno područje, američki profesor geografije C. Sauer (1925.) odredio je kulturni krajolik (Cultural Landscape) kao područje postupno mijenjano čovjekovim djelovanjem. (Sauer, 1925.:37). Kulturni krajolik oblikovan je od prirodnog krajolika djelovanjem kulturnih grupa. Kultura je djelovatelj (agens), a prirodni prostor je medij. Kulturni krajolik je rezultat (Sauer, 1925.:46). Sauer je u koncept krajolika uveo oblike te utjecaj čovjeka i kulture kao snage u stvaranju vidljivih obilježja područja. Na taj su način procesi koji su oblikovali površinu zemlje dobili suštinsko mjesto (Cowley, 2005.:51). Američki geografi, kritičari Sauerove ideje kulturnog krajolika, posebice njegove suprotnosti prirodnom krajoliku, koristili su pojam kulturnog krajolika za krajolike koji su naseljeni (Rowntree, 1996.:128). Pri tome se nepromijenjeni, prirodni krajolici mogu naći samo u područjima koja nikad nisu bila taknuta ljudskom rukom, stoga su za razliku od kultiviranih krajolika (Cultivated Landscapes) dobili naziv divlji krajolici (Wild Landscapes) (Jackson, 1986.:34).

Koncept kulturnog krajolika različito je korišten i razvijan u brojnim akademskim raspravama i istraživanjima, da bi se zamisao o kulturnom krajoliku (Cultural Landscape) i njegovu prepoznavanju kao Svjetskog naslijeđa općih, iznimnih vrijednosti postavila u središte zanimanja stručnjaka UNESCO-a. Konvencija o zaštiti Svjetskog naslijeđa (World Heritage Convention) iz 1992. godine smatra se prvim međunarodnim dokumentom i pravnim instrumentom za prepoznavanje i zaštitu kulturnih krajolika. Konvencijom je kao temeljno određenje krajolika naglašen zajednički rad čovjeka i prirode (UNESCO, 1992.) Time je otvorena mogućnost uključivanja kulturnih krajolika na listu Svjetskog naslijeđa kao dobara koja nisu ni čista prirodna ni čista kulturna forma, već sadrže vrijednosti i jedne i druge vrste (***Operational Guidelines, 1999.b). Kulturni krajolik prikazuje zajedničko djelo prirode i čovjeka, ilustrira razvitak ljudskog društva i naselja kroz povijest, kao integrirani sustav stvoren mecudjelovanjem svoga prirodnog okoliša te društvenih, gospodarskih $i$ kulturnih snaga društva (UNESCO, 1992., art. 37.). Na taj način uspostavljeni koncept pokazuje da kulturni krajolik obuhvaća raznolikost pojavnosti međudjelovanja čovjeka i njegova prirodnog okoliša (Bloemers i sur., 2010.). Kulturni krajolici dijele se u kategorije: namjerno oblikovani, spontano razvijeni i asocijativni (***Operational Guidelines, 1999.b), u okviru kojih se izdvajaju vrste: urbani, ruralni, fortifikacijski, industrijski, pomorski, turistički i sl. te vrste namjerno oblikovanih, kao što su: perivoji, parkovi te niz ostalih. 
U Hrvatskoj se koristi i sintagma „kulturni krajobraz“ (Andlar i sur., 2011.), koja se uglavnom odnosi na poljodjelski kultivirana, agrarna područja. To je na neki način slijed tradicije zaštite etnografskih zona, odnosno ruralnih područja s očuvanom, vrijednom etnološkom baštinom. Sa stanovišta Zakona o zaštiti prirode izdvajaju se pojmovi značajnih te kultiviranih krajobraza kao kategorija prostorne zaštite, koji se odnose na područja prirodnosti te na poljodjelski obrađena područja.

\section{Određenje krajolika u Europskoj konvenciji o krajoliku}

U praćenju razvoja i razumijevanja koncepata „krajolik“ i „kulturni krajolik“ vidljivo je da danas u području humane geografije dolazi do njihova povezivanja i poistovjećivanja, a oba su viđena kao izraz složenog međudjelovanja čovjekovih ideja, društvenih struktura i fizičkih značajki okoliša, pri čemu su prirodne snage i čovjekovo djelovanje nerazmrsivo isprepleteni (Jones, 2003.:76). Pri tome treba naglasiti inovativni pristup i značaj Europske konvencije o krajoliku (COE, 2000.), koja je opisala krajolike kao područja opažena od ljudi čiji je karakter rezultat djelovanja i međudjelovanja prirodnih i/ili ljudskih čimbenika, te se pažnja usmjerava na sve krajolike, bez obzira na vrstu i vrijednosti. Taj se pristup bitno razlikuje od UNESCO-ova stajališta usmjerenog na kulturne krajolike visokih vrijednosti koji su predmet istraživanja samo uskih krugova stručnjaka. Jedna od pretpostavki Konvencije jest potreba za aktivnijim uključivanjem društvene zajednice i pojedinaca u prepoznavanje i brigu o vlastitim krajolicima kao mjestima njihova života. Građanima se omogućava odlučivanje o vrijednostima i značaju krajolika, a time i utjecaj na odluke o zaštiti i upravljanju promjenama. Na taj način sve aktivnosti u krajoliku izravno odražavaju vrijednosne sustave lokalne zajednice te omogućuju primjenu načela supsidijarnosti.

Konvencija prepoznaje da obični i svakodnevni krajolici također imaju svoje značenje jer pridonose bogatstvu i raznolikosti europskih krajolika. Krajolik u svojoj raznolikosti, kao osnovna sastavnica kulturnog naslijeđa, dio kolektivnog i osobnog identiteta, doprinosi stvaranju lokalnih kultura (Fairclough, 2008.5). Svi oblici senzorne i emocionalne percepcije koju stanovnici imaju o svojoj životnoj okolini, prepoznavanje raznolikosti i posebnosti povijesnih i kulturnih obilježja temelj su za stvaranje i očuvanje identiteta prostora (Fowler, 2002.:11). Takav stav uključuje prava i odgovornosti stanovnika te njihovu aktivnu ulogu u procesima donošenja odluka i upravljanju vrijednostima mjesta u kojemu žive. Povezan je s konceptom održivog razvitka, koji podrazumijeva uključivanje kulturnih, društvenih, okolišnih i gospodarskih dimenzija a primjenjuje se na cjelokupni teritorij. Glavna poruka Europske konvencije o krajoliku naglašava da je krajolik neponovljiv i da je svaki njegov dio nekome važan, da su kulturne i prirodne sastavnice određujuće za njegov karakter i da zajedno objašnjavaju njegovu sadašnju pojavnost. Vijeće Europe smatra UNESCO-ov pristup elitističkim jer su za izbor kulturnih krajolika za Listu Svjetskog naslijeđa presudne njihove iznimne vrijednosti, a pridjev kulturni jasno je određen s pozitivnim obilježjima i vrijednostima krajolika (Prieur, 2002.:156). Prema glavnoj zamisli Europske konvencije o krajoliku da svi krajolici moraju biti prepoznati, analizirani i zaštićeni neovisno od njihove vrijednosti usmjerava se pozornost i na tzv. obične krajolike (Lowenthal, 1997.:181). To stvara određene poteškoće, budući da 
su metode zaštite u izravnoj povezanosti i uvijek ovise o stupnju atribucije vrijednosti koja se nastoji zaštiti (Plachter, 1995.:29).

\section{Krajolik je složen entitet; sastavnice i obilježja krajolika}

Teoretska istraživanja krajolika razvijana tijekom 20. stoljeća u posljednjim su desetljećima jačanjem zanimanja za ovu problematiku značajno napredovala (Melnick, 1985.; Jackson, 1986.; Birks, 1988.; Phillips, 1995.; Lowenthal, 1997.; Pedroli, 2000.; Jivén i Larkham, 2003.; Manzo i Perkins, 2006.; Johnson, 2007.). Prihvaćen je stav da krajolik uključuje i kulturna i prirodna obilježja te da sadrži materijalne i nematerijalne elemente (Head, 2000.; Cowley, 2005.). Krajolik predstavlja sintetski i integriran sustav koji uključuje materijalnu, fizičku realnost stvorenu iz stalnih dinamičkih međudjelovanja između prirodnih uvjeta i ljudskih aktivnosti, nematerijalnih vrijednosti i simboličkog značaja (Antrop, 2006.a:181). Krajolik obuhvaća više od izgleda i grupa fizičkih obilježja i struktura koje izražavaju njegovu vizualnu pojavnost, vanjski izgled složenih međuodnosa čovjeka i prirode. On sadrži i često prenosi duhovne vrijednosti, nematerijalne sadržaje društvene zajednice te povezanost s povijesnim događajima ili znamenitim osobama (Mcdowell, 2008.:38).

Krajolik je homogeno područje sastavljeno od sastavnica i procesa koji odražavaju odnose između čovjeka i njegova okoliša. Sastavnice krajolika dijele se na prirodne i antropogene, materijalne i nematerijalne, odnosno biotske, abiotske i kulturne (Mücher i sur., 2003.:23). Strukturna obilježja krajolika odražavaju ne samo prirodnu okolinu već i aspekt povijesti, tj. utjecaj čovjeka, njegova djelovanja i procese tijekom povijesnog razvoja očuvanih u obliku prostornih uzoraka (Crowe i Mitchell, 1988.:29; Antrop, 2006.b:125). Osim podjele na osnovne grupe sastavnica: prirodne i antropogene, važnu ulogu u stvaranju krajolika imaju njihovi međuodnosi, povezanosti, utjecaji i uzročno posljedično djelovanje. Holistička definicija krajolika, kojom je obuhvaćen sveukupni karakter jednog područja (Humboldt, 2010.:14), kao fizionomija čovjekova materijalnog okruženja oblikovana od materijalnih i nematerijalnih sastavnica posljedično utječe na istraživačke metode (Naveh, 2005.:228). Krajolik nije moguće sagledati i interpretirati kao cjelinu, već se istražuje, analizira i vrednuje kroz pripadajuće sastavnice. Na temelju dosadašnjih istraživanja pojedinih autora (Dumbović Bilušić, 2002.:57; Dumbović Bilušić i Obad Šćitaroci, 2007.:265) sastavnice krajolika podijeljene su u osnovne grupe (dijagram):

- prirodne sastavnice: klimatska, reljefna, geološka i hidrološka obilježja, vrste tala, prirodna vegetacija i staništa

- kulturne (antropogene) sastavnice: prostorna organizacija (kompozicija), naselja i građevine, prometne komunikacije, poljodjelske površine, ostali oblici korištenja zemljišta, građevine malog mjerila, oprema prostora, arheološki ostatci...

- oblikovne (fizionomijsko-morfološke) sastavnice: uzorci, razmjeri, proporcije, linije razgraničenja, oblici, boje, dominante, vizure...

- nematerijalne sastavnice: asocijativne, duhovne, identitetske, simboličke, tradicijske, običajne; slikarski, literarni, glazbeni i ostale vrste izričaja, genius loci i ostalo. 


\section{Značenja krajolika i stvaranje identiteta mjesta, geniusa loci}

Krajolik je egzistencijalni prostor, ${ }^{5}$ sustav percepcijskih predodžbi - slika okoline, strukturiran vertikalnim i horizontalnim slojevima gdje je prirodna podloga - horizontalni sloj na kojoj čovjek svojim naseljima, putovima, načinom korištenja zemljišta te svojim svakodnevnim životom uspostavlja njegovu vertikalnu osovinu. Navedeni slojevi povezani su različitim načinima međudjelovanja (Norberg-Schulz, 1975.:27). $\mathrm{Na}$ taj način strukturiran krajolik određen je vlastitim bićem, duhom mjesta, geniusom loci, koji određuje njegov karakter, prepoznatljivost i identitet (Norberg -Schulz, 1982.:11). Krajolik može biti prostor visoke prepoznatljivosti koji kod promatrača stvara jasnu sliku o prostoru, a time i snažan osjećaj pripadnosti (Lothian, 1999.:177). Može biti razmatran i kao dom zajednice koja u njemu živi (Pedroli, 2000.:145). Kao naslijeđeni, egzistencijalni prostor izravno je povezan s osjećajem pripadnosti i zavičajnosti, pri čemu zavičajnost, kao preduvjet pripadanju i povezanosti, ima ključno značenje u stvaranju prepoznatljivosti (Bachelard, 2000.:29).

Raznolikosti obilježja i značenja krajolika kao integralnog sustava sudjeluju u stvaranju jedinstvenosti i njegova identiteta (Antrop, 2000.:30), pri čemu suštinska obilježja određuju cjelovitost karaktera stvorenog međudjelovanjem prirode i čovjeka te stalnost promjena (Antrop, 2005.:20). Unatoč stalnim fizičkim promjenama, jedinstvenost i višestruka značenja krajolika određujući su elementi za stvaranje prepoznatljivosti i identiteta (Proshansky, 1978.:147). Čovjek kao pojedinac aktivno sudjeluje u stvaranju i oblikovanju krajolika a istovremeno iz njega izvlači značenja (Proshansky, 1978.:159). Kroz međudjelovanje sa svojim fizičkim okruženjem čovjek stvara i oblikuje krajolik te istovremeno stječe iskustva i razvija kognitivne strukture koje predstavljaju sjećanja, ideje, osjećaje, stavove, vrijednosti, sklonosti, značenja, koncepcije ponašanja i iskustva vezana uz krajolik (Gustafson, 2001.:251). Pri tome društvena i simbolička značenja krajolika ovise o etičkim i ostalim ideološkim stajalištima pojedinaca i društvenih zajednica (Relph, 1976.:42), a ikonografija krajolika nastoji objasniti njegov status kao kulturne slike, slikovitog načina prikazivanja, strukturiranja te simboličkog značenja (Cosgrove i Daniels, 1988.:40). Identitet krajolika pri tome je usko povezan sa stupnjem njegove jedinstvenosti i načinom na koji određeno područje može biti individualizirano i karakterizirano (Antrop, 2005.:21).

Krajolik se sagledava kao integrativna kategorija koja ujedinjuje više razina međudjelovanja, a sastoji se od triju glavnih značajki: zemljopisnog položaja, materijalnog

5 Na tragu Heideggerove teze kojom je prvi ustvrdio da je egzistencija prostorna, niz autora (Lefebvre i dr.) napušta apstraktni smisao Euklidovskog prostora i uvode relacijski pristup poimanju prostora kao egzistencijalne kategorije i odnosa čovjeka prema njemu. Knjiga K. Lyncha Slika jednog grada (1960.) polazna je točka za istraživanje u području egzistencijalnog i arhitektonskog prostora. Istraživanja C. N. Schulza u knjigama Egzistencija, prostor i arhitektura (1975.) i genius loci - Landschaft, Lebensraum, Baukunst (1982.) pokazuju da čovjekov opstanak ovisi o uspostavljanju osmišljene i koherentne slike sredine u kojoj živi kao višeznačnom, složenom, ali strukturiranom prostoru. P. Boudon (2006.) tvrdi da prostor po sebi nije više euklidski, nego projekcijski ili topološki, a arhitektonski prostor postoji samo ako je koncipiran. 
oblika te smisla i vrijednosti (Gieryn, 2000.:465). Važno svojstvo krajolika jest fizikalnost, odnosno geografski položaj koji upućuje na to da je on konačan, logično smješten, elastičnih granica koje su određene, iako su otvorene (Gieryn, 2000.:466). Povezuje utilitarne vrijednosti s nematerijalnim elementima, kao što su osjećaj pripadnosti, povezanosti, ljepote i duhovnosti. Čovjekova je povezanost s krajolikom višestruka, složena i ispunjena značenjem; materijalne i nematerijalne vrijednosti nerazdvojne su, obje su sastavni dio značenja koje ljudi dodjeljuju krajoliku (Cheng i sur., 2003.:87). Svaki krajolik izražava jedinstveni osjećaj i duh mjesta (Spirit of Place, genius loci), a utjelovljuje značajke topografskih obilježja koje mjestu daju poseban karakter te time određuju njegov identitet (Norberg-Schulz, 1982.:35). Genius loci oblikovan je s nekoliko čimbenika koji su, bez obzira na promjene, postojani a uključuju oblike, uzorke fizičkih obilježja, funkciju i socijalne strukture te kulturno značenje krajolika. Pri tome se pojam genius loci odnosi na zbroj svih fizičkih $i$ simboličkih vrijednosti u krajoliku (Jiven i Larkham, 2003.:70) a čine ga četiri razine: topografija Zemljine površine, kozmološki svjetlosni uvjeti, građevine te simbolička i egzistencijalna značenja kao odgovor čovjeka na ograničenja i prirodne resurse mjesta (Norberg-Schulz, 1982.:56; Proshansky 1978.:160).

Prepoznavanje identiteta krajolika usko je povezano s percepcijom i njegovim odrazom u očima promatrača (Appleton, 1996.:12). Primjerice, tradicijski krajolici sadrže opsežnu povijest mjesta i pripadajuće regije prepoznate kroz kompoziciju i strukture, dok se nematerijalni čimbenici preklapaju s oblicima simbola, znakova i memorije (Cosgrove, 1984.:28; Schama, 1995.:31). U nekim se krajolicima simboličke vrijednosti prenose kroz prostorne orijentire i znakove (landmarks), koji omogućavaju njegovu prostornu i vremensku prepoznatljivost (Tilley, 1992.:47; Lipovac i Dumbović Bilušić, 2011.:699). Svaki krajolik, zbog svoje jedinstvenosti, neponovljive kompozicije, ustroja i karaktera, daje različite podatke za stvaranje percepcije, tj. govori drugu prostornu priču (Azaryahu i Foote, 2001.:22). Krajolik koji je očuvan u svom prostornom ustroju može biti izvor podataka o prošlosti, uključuje prikaz prostornih, topografskih elemenata i antropogenih struktura (građevina, oznaka, natpisa i sl.) koji ilustriraju prostorne ili kronološke odnose s određenim povijesnim razdobljima. Na taj način razmatran, krajolik je palimpsest, arhiv na otvorenom, koji sadrži podatke o razvoju određene zajednice i njezine povezanosti s pripadajućim okolišem, u kojemu je vidljivo međudjelovanje s prirodnim uvjetima, zadanostima ili ograničenjima (Haber, 1995.:38).

\section{Integralni pristup istraživanjima krajolika}

Osim fizičkih, krajolik sadrži i nematerijalne, estetske, vizualne i ostale percepcijske vrijednosti, a u istraživanju svake od navedenih važno je razumjeti ga u kontekstu njegova prostora i vremena (Tress i sur., 2006.:29). Istraživanja koja su još prije tridesetak godina uglavnom provodili stručnjaci iz područja kulturne geografije bila su usmjerena prema fizičkim obilježjima krajolika, međutim u današnje vrijeme prihvaćen je stav da su krajolici odraz čovjekovih aktivnosti te da su usko povezani s kulturnim vrijednostima (Howard, 2003.:22; Pressouyre, 2007.:9). Budući da krajolici u svojim kombinacijama prostornih sastavnica i povijesnih razdoblja u kojima su 
oblikovani reprezentiraju njihove političke, gospodarske, socijalne i kulturne odnose (Kelly, 2001.:65), oni postaju predmetom istraživanja društvenih i humanističkih područja. Krajolici koji su se razvijali kroz duža vremenska razdoblja u kojima su i čovjekove aktivnosti bile u stalnim mijenama sadrže raznolike i složene slojeve značenja koja se mogu analizirati kroz razne vrste istraživanja: povijesna, arheološka, geografska, sociološka, etnografska i ostala. U suvremenim međunarodnim istraživačkim pristupima krajolik je postao središtem interesa širokoga kruga disciplina: od prirodnih, tehničkih do humanističkih (Makhzoumi i Pungetti, 2008.:330).

Krajolici se kao područja kontinuiranih procesa sagledavaju i istražuju u vremenskom kontekstu, kroz analize povijesnog razvoja, ocjene današnjeg stanja te s vizijama i scenarijima budućeg razvitka (Ermischer, 2004.:179). Istraživanja krajolika koja se provode u humanističkim i društvenim pristupima usmjerena su na analize utjecaja čovjeka u promjenama fizičkog izgleda krajolika s težištem na povijesnim promjenama i utjecajima čovjeka, tipovima promjena, značenju krajolika za različite društvene grupe, povezanostima s kulturom i tradicijom. U pristupima biotehničkih i prirodnih znanosti pozornost je usmjerena na prirodne sastavnice i okolišne uvjete. Iako još uvijek postoje podjele i prepreke među raznim disciplinama, pojedina istraživanja krajolika razvila su se u grupe međusobno povezanih, simbiotskih disciplina koje prelaze tradicijske akademske razlike (Naveh, 2005.:228; Manzo i Perkins, 2006.:333). Takav pristup omogućuje integrirana istraživanja povijesnog razvoja i današnjega stanja krajolika. Integrativna priroda istraživanja krajolika u posljednjem je desetljeću postala subjektom različitih disciplina i pristupa: prirodnih i kulturnih, vizualnih, društvenih, gospodarskih i sl. ${ }^{6}$ Međutim u stvarnom krajoliku ove dimenzije ne postoje odvojeno (Bohnet i Smith, 2006.:140), on je sastavljen od različitih karakteristika i vrijednosti - od biofizičkih, ekološko-okolišnih, kulturno-povijesnih, socioloških, psiholoških i ostalih (Tilley, 1992.:35). Napuštanjem determinizma pomiču se granice između istraživačkih disciplina, a koncept krajolika oslobođen čvrstih okvira, širokog značenja i sveobuhvatnog raspona mogućnosti (Bender, 1993.:205) otvara mogućnosti za suradnju različitih područja.

\section{Zaključak}

U radu se induktivno-deduktivnom metodom, analizom različitih teorijskih pristupa prikazalo značenje pojmova krajolika, krajobraza i kulturnog krajolika kao doprinos njihovu jednoznačnom razumijevanju i tumačenju u primjeni u Hrvatskoj. Višestoljetnim razvojem određenja pojma prihvaćen je stav da je krajolik bumani element okoliša, materijalni i nematerijalni okvir svakodnevnog života čovjeka (Naveh i Liebermann, 1999.). Koncept krajolika u prvim se desetljećima 20. stoljeća uglavnom odnosio na seoska područja u smislu značenja izraza oblikovati zemlju. Naglasak je

$\mathbf{6}$ O tome svjedoče brojni znanstveni skupovi, istraživanja, publikacije i knjige na temu krajolika koje sadrže interdisciplinarne pristupe. Krajolik je predmet istraživanja različitih znanstvenih i stručnih područja: arheologije, kulturne geografije, ekologije, povijesti, krajobrazne arhitekture, pejsažne i perivojne arhitekture, urbanizma, prostornog planiranja, psihologije, sociologije.. 
bio na etimološkim korijenima i određenju pojma krajolika (landscape, Landschaft), čije sastavne riječi doslovno označavaju radnje koje se odnose na oblikovanje zemlje, odnosno promjenu prirodnog stanja. Danas je koncept proširen i na ostala područja, pa i urbana, tako da se odnosi na cjelokupni prostor percipiran od čovjeka. Za razliku od okoliša, kao fizičke okoline čovjekova života, krajolik ne postoji bez percepcije čovjeka, što ga povezuje s konceptom identiteta. Utvrđena je dualnost pojma krajolika, koji se odnosi i na prostor te na mentalni koncept, predodžbu toga prostora u kojemu su kulturne i povijesne značajke usko povezane s fizičkim i prirodnim obilježjima. Povezanost krajolika sa zajednicom koja ga kroz društveni proces stvaranja i korištenja mijenja i percipira njegovo je identitetsko određenje koje formira njegov genius loci. Stoga je suštinsko mjesto za razumijevanje krajolika njegova kulturna dimenzija, stvorena čovjekovim utjecajem, kao rezultat njegova međudjelovanja s prirodnim uvjetima. Na taj način interpretiran, pojam se krajolika odnosi na sveukupni prostor, na razlikovna obilježja zemljopisno određenog područja te na procese i utjecaje djelovanja čovjeka.

Prema tumačenjima kulturne geografije pojam krajolika moguće je poistovjetiti s pojmom kulturnog krajolika upravo zbog utjecaja čovjeka i njegovog odgovora uvjetima topografskog smještaja. Zbog utjecaja i djelovanja čovjeka kulturni se krajolik suštinski razlikuje od prirodnog krajolika, čija je pojavnost rezultat prirodnih procesa, bez ili s vrlo neznatnim utjecajem čovjeka. U ovakvom se poimanju pojam kulturnog krajolika ne odnosi samo na krajolike visokih vrijednosti prepoznate kao kulturno naslijeđe, već se odnosi na sve krajolike, bez obzira na stupanj njihove vrijednosti. U Hrvatskoj se za krajolike koji su promijenjeni od prirodnog stanja - kulturne, koristi i naziv „kultivirani“, međutim značenje ove riječi upućuje na kultiviranje, obradu zemlje, te stoga ne može biti ekvivalent pojmu „kulturni“. Slijedom stava da je krajolik nastao kao rezultat čovjekova boravljenja i korištenja te da uključuje prirodne i antropogene sastavnice koje su međusobno isprepletene i međuovisne proizlazi da svaki krajolik po sebi jest kulturna, antropogena kategorija te da u korištenju pojma nije potrebno dodavati pridjev „kulturni“. Kako bi se izbjegle zabune, ispravnija oznaka takvoga krajolika bio bi pridjev „antropogeni“. Za razliku od antropogenih prirodni se krajolici mogu naći samo u rijetkim područjima koja nisu promijenjena čovjekovim utjecajem.

Kulturnim krajolicima smatraju se oni koji se izdvajaju od svoje okoline po posebnostima i vrijednostima izgleda, pojavnosti, oblikovanja, povijesnog razvoja ili po velikoj zastupljenosti pojedinačnih kulturno-povijesnih dobara. Krajolik se u tom kontekstu razmatra kao kulturno naslijeđe s kulturnim, povijesnim, umjetničkim, ekološkim, etnološkim i simboličkim vrijednostima i značajem, kao kategorija baštine. On postaje kulturnim dobrom nakon provedenog procesa vrednovanja njegovih obilježja; prirodnih i antropogenih sastavnica koje u zajedničkom sklopu odražavaju umjetničke, kulturne, povijesne, okolišne, društvene i ostale povezanosti s prirodnim okolišem. Kulturni krajolik pri tome ne obuhvaća samo ruralna, poljodjelski kultivirana područja, već se odnosi i na ostale vrste krajolika nastale čovjekovim djelovanjem, kao što su: urbani, industrijski, fortifikacijski, i sl. Sintagma „kulturni krajobraz“, koja se nadovezuje na tradiciju zaštite tzv. etnografskih zona, u dosadašnjim se istraživanjima uglavnom odnosi na povijesne, agrarne krajolike. Treba naglasiti i 
postojanje značajnih i kultiviranih krajobraza koji se štite temeljem Zakona o zaštiti prirode, a koji po svojem određenju također pripadaju kategoriji kulturnih krajolika.

Posebnost, a ujedno i bogatstvo hrvatskog jezika sastoji se u tome da koristi više riječi za isti pojam, pri čemu su krajobraz i krajolik riječi hrvatskog jezika, dok je riječ „pejsaž“ tuđica. Iako se prema lingvističkom tumačenju smatraju istoznačnicama, koncepti „krajobraz“ i „krajolik“ mogu se pojmovno razdvojiti, pri čemu je potonji obuhvatniji. Za razliku od pojma krajobraza, koji se odnosi uglavnom na manja područja i njihov oblikovni aspekt te na elemente prirodnosti, odnosno na područja u kojima pretežu prirodne sastavnice, pod pojmom krajolika podrazumijeva se ukupnost pojavnosti topografski određenog područja, njegov cjeloviti lik, odnosno karakter, stvoren djelovanjem čovjeka na prirodni okoliš tijekom vremena. Krajolik se kao širi pojam odnosi na cjeloviti karakter određenog predjela i pri tome uključuje i ravnopravno povezuje obje grupe sastavnica: prirodne i kulturne, zajedno s pripadajućim nematerijalnim obilježjima.

Obuhvatnost i fleksibilnost krajolika kao koncepta jest središnje mjesto njegova razumijevanja koje proizlazi iz stava da je krajolik koncept između. Istraživanja i bavljenje pitanjima prepoznavanja i zaštite krajolika stoga ne mogu biti predmetom samo jednog znanstvenog područja, već istraživanjima krajolika treba pristupiti kao interdisciplinarnome području. Takav pristup koji postavlja na istu razinu razumijevanje i zaštitu i kulturnih i prirodnih sastavnica te ukupnost materijalnih i nematerijalnih aspekata otvara nove mogućnosti za suradnju različitih znanstvenih područja. Jedna od budućih zadaća jest uspostava integriranih istraživanja, interdisciplinarnog karaktera, preduvjeta za stvaranje društvene, okolišne i gospodarske dobrobiti krajolika u Hrvatskoj.

\section{Literatura}

1. Aitchson, J. (1995). Cultural landscape in Europe: a Geografical Perspective, u: Cultural Landscapes od Universal Value, (ur. von Droste, B.; Plachter, H. and Rössler, M.): 272-288. Sttutgart, New York: Fischer Verlag, Jena.

1. Andlar, G.; Aničić, B.; Pereković, P.; Rechner Dika, I.; Hrdalo, I. (2011). Kulturni krajobraz i legislativa - stanje u Hrvatskoj. Društvena istraživanja, 3 (113): 813-835.

2. Anić, V. i Goldstein, I. (2004). Veliki rječnik hrvatskog jezika. Zagreb: Novi liber.

3. Antrop, M. (2000). Where are the Genii Loci?, u: Pedroli, B. (ed.). Landscape, Our Home: Essays on the Culture of the European Landscape as a Task. Indigo, Zeist: 29-34.

4. Antrop, M. (2005). Why Landscapes of the Past are important for the Future. Landscape and Urban Planning, 70: 19-27.

5. Antrop, M. (2006.a). Sustainable Landscapes: Contradictionm, Fiction or Utopia?. Landscape and Urban Planning, 75: 187-197.

6. Antrop, M. (2006.b). From holistic Landscape Syntesis to Transdisciplinary Landscape Managment, in: Tress, B.; Tress, G.; Fry, G.; Opdam, P. (eds.). From Landscape Research to Landscape Planning, Aspects of Integration, Education and Application. Dordrecht: Spriger: 125-164. 
7. Appleton, J. (1996). The Experience of Landscape. Chichester.

8. Azaryahu, M. and Foote, K. E. (2001). Historical Space as Narrative Medium: On the Configuration of Spatial Narratives of Time at Historical Sites. GeoJournal, 35: 21-32.

9. Bachelard, G. (2000). Poetika prostora. Zagreb: Ceres.

10. Bender, B. (1993). Introduction: Landscape, Meaning and Action, in: Bender, B. (ed.). Landscapes, Politics and Perspectives. Oxford: Berg: 8-21.

11. Birks, H. H. (1988). The Cultural Landscape - Past, Present and Future. Cambridge: Cambridge University Press.

12. Bloemers, T.; Kars, H.; van der Valk, A.; Wijnen, M. (2010). The Cultural Landscape and Heritage Paradox. Amsterdam: Springer.

13. Bohnet, I. and Smith, D. M. (2006). Planning Future Landscapes in the Wet Tropics of Australia: A Social-ecological Framework. Landscape and Urban Planning, 80: 137-140 [3].

14. Casey, E. S. (1998). The Fate of Place: A Philosophical History. Berkeley: University of California Press.

15. Claval, P. (2004). The Languages of Rural Landscapes, in: Palang, H. (ed.). European Rural Landscapes: Persistence and Change in a Globalising Environment. Dordrecht: Springer: 11-41.

16. Cheng, A. S.; Kruger, L. E. and Daniels, S. E. (2003). "Place" as an Integrating Concept in Natural Resource Politics: Propositions for a Social Science Research Agenda. Society and Natural Resources, 16 (2): 85-92 [6]

17. Cosgrove, D. (1984). Social Formation and Symbolic Landscape. London: Croom Helm.

18. Cosgrove, D. and Daniels, S. (1988). The Iconography of Landscape, Essays on the Symbolic Representation, Design and Use of Past Environments. Cambridge: Cambridge University Press.

19. Cosgrove, D. (1997). Cultural Landscapes, in: Unwin, T. (ed.). Europe: a Modern Geography. London: Addisson Wesley Longman: 65-81.

20. Cowley, J. (2005). Cultural Landcsape. Washington: National Park Service.

21. Crowe, S. and Mitchell, M. (1988). The Pattern of Landscape. London: Packard Publishing.

22. Delort, R. and Kuster, H. (2004). Geschichte der Landschaft in Mitteleuropa. Von Eiszeit bis zur Gegegnwart, in: Dietrich, M. and van der Straaten, J. (eds.). Cultural Landscape and Land Use, The Nature Conservation - Society Interface. Dordrecht, Netherlands: 5-16.

23. Dower, M. (1993). Cultural Landscapes - What are They and What are Important, in: Cultural Landscape - Historic Landscape. Budapest-Keszthely, 7-11.06.1993: 37-45.

24. Dumbović Bilušić, B. (2002). Kulturni krajolik - jedinstvo prirodne i kulturne baštine. Građevinar, 54 (1): 57-61.

25. Dumbović Bilušić, B. and Obad Šćitaroci, M. (2007). Kulturni krajolici u Hrvatskoj - identifikacija i stanje zaštite. Prostor, 15 (2007) 2 (34): 260-271.

26. Ermischer, G. (2004). Mental Landscape. Landscape as Idea and Concept. Landscape Research, 29 (4): 171-183.

27. Fairclough, G. (1999). Yesterday's World, Tomorrow's Landscape. London: English Heritage. 
28. Fairclough, G. (2008). New Heritage - People, Landscape and Change, in: Fairclough, G.; Harrison, R; Jameson, J. H.; Schofield, J. (eds.). The Heritage Reader. London, New York: 3-18.

29. Fowler, P. (2002). The Past in Contemporary Society: Then, Now. London: Routledge.

30. Gieryn, T. F. (2000). A Space For Place In Sociology, Annu Revial Sociology, 26: 463-496.

31. Gosden, C. and Head, L. (1994). Landscape - A Usefully Ambiguous Concept, Archaeology in Oceania, 29: 113-116.

32. Gustafson, P. (2001). Meanings of Place: Everyday Experience and Theoretical Conceptualizations, Journal of Environmental Psychology, 21: 16-26.

33. Haber, W. (1995). Concept, Origin and Meaning of Landscape, in: von Droste, B.; Plachter, H.; Rössler, M (eds.). Cultural Landscapes of Universal Value. Sttutgart, New York: UNESCO, Gustav Fischer Verlag, Jena: 38-42.

34. Head, L. (2000). Cultural Landscapes and Environmental Change, New York: Oxford University Press.

35. Howard, P. (2003). Heritage Managment, Interpretation, Identity. Hampshire: Ashgate Publishing.

36. Humboldt, A. (2010). Predavanja o kozmosu. Zagreb: Scarabeus naklada.

37. Jackson, J. (1986). Discovering the Vernacular Landscape. New Haven, London: Yale University Press.

38. Jivén, G. and Larkham, P. J. (2003). Sense of Place, Authenticity and Character: a Commentary. Journal of Urban Design, 8 (1): 67-81.

39. Johnson, M. (2007). Ideas of Landscape. Oxford: University Press.

40. Jones, M. (2003). The Concept of Cultural Landscape: Discourse and Narrativies, in: Palang, H. and Fry, G. (eds.). Landscape Interfaces, Cultural Heritage in Changing Landscapes. Dordrecht: Springer: 76-89.

41. Keisteri, T. (1990). The Study of Changes in Cultural Landscapes, in: Geographical Society of Finland. Helsinki.

42. Kelly, R. (2001). The Cultural Landscape, Planning for a Sustainable Partnership between People and Place, in: Edited Papers from a Conference on Cultural Landscapes. Oxford, May 1999: 64-82, ICOMOS UK, London.

43. Klaić, B. (1982). Rječnik stranih riječi. Zagreb: Nakladni zavod Matice Hrvatske.

44. Kučan, A. (1998). Krajina kot nacionalni simbol. Ljubljana: Znanstveno in publicistično središče.

45. Ladan, T. (2000). Riječi, značenje, uporaba, podrijetlo. Zagreb: ABC naklada.

46. Lipovac, N. and Dumbović Bilušić, B. (2011). Role of Historic and Contemporary Spatial Accents defining the City Identity: Zagreb Skyline, 4th IC Hazards on Modern Heritage - Importance of Place, Sarajevo: 694-708.

47. Lothian, A. (1999). Landscape and the Philosophy of Aesthetics: Is Landscape Guality inherent in the Landscape or in the Eye of the Beholder?. Landscape and Urban Planning, 44: 177-198, [11].

48. Lowenthal, D. (1997). European Landscape Transformations. The Rural Residue, in: Groth, P. and Bressi T. W. (eds.). Understanding Ordinary Landscapes. New Haven: Yale University Press: 180-188.

49. Makhzoumi, J. and Pungetti, G. (2008). Landscape Strategies, in: Vogiatzakis, I. N.; Pungetti, G.; Mannion, A. M. (eds.). Mediterranean Island Landscapes: Natural and Cultural Approaches. Heidelberg: Springer: 325-345. 
50. Manzo, C. and Perkins, D. (2006). Finding Common Ground: The Importance of Place Attachment to Community Participation and Planning. Journal of Planning Literature, 20: 332-336 [12].

51. Mcdowell, S. (2008). Heritage, Memory and Identity, in: Brian, G. and Howard, P. (eds.) The Ashgate Research Companion to Heritage and Identity. Ashgate, Aldershot: 37-54.

52. Melnick, R. (1985). Landscape Thinking, Cultural Resources Management, Technical Bulletin, 8 (1) National Park Service, ASLA [crm.cr.nps.gov/archive/081/8-1-all.pdf 20.12.2010.].

53. Morris P. and Therivel, R. (1995). Methods of Environmental Imact Assessment. London: UCL Press.

54. Mücher, C. A.; Bunce, R. G. H.; Jongman, R. H. G.; Klijn, J. A.; Koomen, A. J. M.; Metzger, M. J.; Washer, D. M. (2003). Identification and Characterisation of Environments and Landscapes in Europe, Alterra rapport 832, Alterra, Wageningen.

55. Naveh, Z. and Liebermann, A. (1999). Landscape Ecology:Theory and Application. Berlin, Heidelberg, New York: Springer.

56. Naveh, Z. (2005). Epilogue: Toward a Transdisciplinary Science of Ecological and Cultural Landscape Restoration. Restoration Ecology, 13 (1): 228-234.

57. Norberg-Schulz, C. (1975). Egzistencija, prostor $i$ arbitektura. Beograd: Građevinska knjiga.

58. Norberg-Schulz, C. (1982). Genius Loci-Landschaft, Lebensraum, Baukunst. Hamburg: Klett-Cotta Verlag.

59. Palang, H. (2003). Landscape interfaces: Introduction, in: Palang, H. and Fry, G. (eds.). Landscape Interfaces: Cultural Heritage in Changing Landscapes. Dordrecht: Kluwer Academic Publishers: 1-14.

60. Pannell, S. (2006). Reconciling Nature and Culture in a Global Context: Lessons from the World Heritage List. Cairns: James Cook University.

61. Pedroli, B. (2000). Landscape - Our Home, Lebensraum, Landschaft, Essays on the Culture of the European Landscape as a Task. Stuttgart: Indigo.

62. Pendelbury, J. (2009). Conservation in the Age of Concensus. Abingdon: Routledge.

63. Phillips, A. (1995). Cultural Landscapes: an IUCN Percpective, in: von Droste, B.; Plachter, H. and Rössler, M. (eds.). Cultural Landscapes of Universal Value. Jena, Stuttgart, New York: Fischer Verlag: 380-92.

64. Plachter, H. (1995). Functional Criteria for the Assessment of Cultural Landscape, in: von Droste, B.; Plachter, H. and Rössler, M. (eds.). Cultural Landscapes of Universal Value. Jena, Stuttgart, New York: Fischer Verlag: 26-31.

65. Porteaus, J. D. (1996). Environmental Aesthetics: Ideas, Politics, and Planning. New York: Routledge.

66. Pressouyre, L. (2007). Introduction, in: Zangheri, L. (ed.). ICOMOS International Day for Monuments and Sites-Cultural Landscapes, Annual Report ICOMOS, Roma [14].

67. Prieur, M. (2002). Legal Provisions for Cultural Landscape Protection in Europe, in: Cultural Landscapes the Challenge for Conservation. World Heritage Papers 7, Ferrara: 150-156.

68. Proshansky, H. (1978). The City and Self-Identity. Environment and Behavior, 10 (2): 147-169. 
69. Ratzel, F. (1901/1902). Die Erde und das Leben. Leipzig [socgeo.ruhosting.nl/ html/files/geoapp/Werkstukken/SpaceandNature.pdf. 10.12.2011.].

70. Relph, E. (1976). Place and Placelessness. London: Pion Lt.

71. Rössler, M. (1999). Linking Nature and Culture: World Heritage Cultural Landscapes, in: Cultural Landscapes: the Challenges of Conservation. Paris: UNESCO: $10-15$.

72. Sauer, C. O. (1925). The Morfology of Landscape. Publications in Geografy, 2 (2): 19-53.

73. Schama, S. (1995). Landscape and Memory. London: Harper Collins.

74. Tress, B.; Tress, G.; Fry, G.; Opdam, P. (2006). From Landscape Research to Landscape Planning, Aspects of Integration, Education and Application. Dordrecht: Springer.

75. Tilley, C. (1992). A Phenomenology of Landscape: Places, Paths and Monuments. Oxford: Berg.

76. *** (1973.), Westermann Lexikon der Geographie, Georg Westermann Verlages von Dr. Wolf Tietze, Braunschweig

77. ${ }^{* * * *}$ (1999.a), Krajolik - sadržajna i metodska podloga Krajobrazne osnove Hrvatske, Ministarstvo prostornog uređenja, graditeljstva i stanovanja, Zavod za prostorno planiranje; Agronomski fakultet Sveučilišta u Zagrebu, Zavod za bilje i krajobraznu arhitekturu

78. ***: (1999.b), Operational Guidelines for the Implementation of the World Heritage Convention, UNESCO Intergovernmental Committee for the Protection of the World Cultural and Natural Heritage World Heritage Centre, Paris

79. Zakon o zaštiti i očuvanju kulturnih dobara, (NN 69/99, 151/03, 157/03, 87/09, $88 / 10,61 / 11$ i 25/12).

80. Zakon o potvrđivanju Konvencije o europskim krajobrazima, (NN 12/02 i 11/04.).

81. Zakon o zaštiti prirode, (NN 70/05, 139/08 i 57/11).

82. Zakon o prostornom uređenju i gradnji, (NN 76/07, 38/09, 55/11 i 90/11).

83. Council of Europe (2000). European Landscape Convention. Firenza.

84. UNESCO (1992). World Heritage Convention. Paris. 
Pregledni rad

Biserka Dumbović Bilušić

Ministry of Culture of the Republic of Croatia, Directorate for the Protection of Cultural Heritage,

Zagreb, Croatia

e-mail:bbilusic@gmail.com

Contribution to the Interpretation of the Term Landscape as a Cultural Entity

\begin{abstract}
In this paper we analyse the content and definition of the term landscape/krajolik which is often interpreted in different ways due to its multiple meaning. In the Croatian language additional difficulties and further disagreement occur because of the use of another word (krajobraz) for the same term. Inductive deductive method explains the origin and meaning of the term landscape which refers to physical space and its perception. Landscape as existential space is a complex system which consists of physical components, features and processes and is important in the creation of place identity. Terms "krajolik" and "krajobraz" can be conceptually separated. In contrast to the landscape/krajobraz, which refers mainly to areas where natural elements predominate, the notion of landscape/krajolik as a broader term refers to the complete character of a certain area and equally includes and connects both groups of components, natural and cultural, together with their intangible characteristics. Therefore, landscape research, recognition and protection cannot be the subject of a single scientific field but interdisciplinary approach is called for.
\end{abstract}

Key words: landscape (krajolik/krajobraz), cultural landscape, identity of place, interdisciplinary approach. 